\title{
ANALYSIS OF THE GENETIC DIVERSITY OF VANCOMYCIN-RESISTANT STAPHYLOCOCCUS AUREUS
}

\author{
Geraldo B. Melo*; Michelle C. Melo; Alexandre P. Gama; Karinne S. Carvalho; Teresa C. Jesus; Ana M. Bonetti; \\ Paulo P. Gontijo Filho
}

Instituto de Ciências Biomédicas, Departamento de Microbiologia, Universidade Federal de Uberlândia, MG, Brasil

Submitted: October 20, 2004; Returned to authors for corrections: March 21, 2005; Approved: April 25, 2005

\begin{abstract}
Methicillin-resistant Staphylococcus aureus (MRSA) and methicillin-resistant coagulase-negative staphylococci (MRCoNS) are among the most frequent causes of hospital infections worldwide, thus justifying the increasing use of vancomycin. In this study, we evaluated the presence of glycopeptide-resistant staphylococci, in 41 patients hospitalized in the Clinical Hospital of the Federal University of Uberlândia in Uberlândia, MG, who were being treated with vancomycin. All isolates were plated on Mueller-Hinton agar containing vancomycin. Vancomycin resistance was confirmed by surface growth after incubation for 24-48 $\mathrm{h}$ at $35^{\circ} \mathrm{C}$. Heteroresistance was evaluated by plating with a large inoculum $\left(10^{8} \mathrm{CFU} / \mathrm{mL}\right)$. One patient with nephritis who was on a hemodialysis program was diagnosed with the phenotype isolate of vancomycinintermediate Staphylococcus aureus (VISA) (CIM $=8 \mu \mathrm{g} / \mathrm{mL}$ ) and in eight patients, strains of heteroresistant Staphylococcus corresponding to the hVISA phenotype were isolated. In addition to the extended use of vancomycin, other risk factors associated with the presence of these microorganisms included the use of three or more antimicrobial agents, surgery, and three or more invasive procedures. Molecular analysis by randon amplified polymorphic DNA - polymerase chain reaction (RAPD-PCR) showed two clusters involving two samples each one of them, in surgical patients, with temporal and spatial relationship and isolates similarity concerning the susceptibility range to antimicrobial agents.
\end{abstract}

Key words: Hospital epidemiology, vancomycin-resistant Staphylococcus, RAPD-PCR

\section{INTRODUCTION}

Methicillin/oxacillin-resistant Staphylococcus aureus account for more than $50 \%$ of hospital staphylococci $(3,18)$, and has led to an increase in the use of vancomycin $(11,23)$. In Brazil, the situation is particularly serious because of the limited use of standard diagnostic microbiological procedures in hospitals (8) and also because of the empirical use of antimicrobial agents $(5,14,17)$.

Staphylococcus aureus and mainly coagulase-negative staphylococci isolates resistant to methicillin/oxacillin and with a reduced susceptibility to glycopeptides were reported in Japan, United States, Europe and Asia at the end of the 1980s (13). The resistant phenotypes commonly found in most hospitals include VISA (vancomycin-intermediate Staphylococcus aureus) and VICoNS (vancomycin-intermediate coagulase negative Staphylococcus) which show intermediate resistance, VRSA (vancomycin-resistant Staphylococcus aureus) for which the minimum inhibitory concentration (MIC) of vancomycin is $\geq 32 \mu \mathrm{g} / \mathrm{mL}$, and hVISA/hVICoNS a heteroresistant form with a MIC $\geq 8 \mu \mathrm{g} / \mathrm{mL}(13,15,23)$. Recently a VRSA isolate obtained from the catheter of a diabetic patient on hemodialysis showed clusters of vanA resistance genes (4).

The first epidemiological report of these microorganisms in a Brazilian hospital was done in the city of São Paulo (6), followed by a report from Rio de Janeiro (16). An outbreak of VISA with four isolates from a burn unit in a hospital in São Paulo has also been described (17).

*Corresponding Author. Mailing address: Instituto de Ciências Biomédicas, Departamento de Microbiologia, Universidade Federal de Uberlândia, Av. João Naves de Ávila, 692. 38400-042, Uberlândia, MG, Brasil. Tel.: (+5534) 3218-2236, Fax: (+5534) 3218-2332. E-mail: geraldom@umuarama.ufu.br 
The aim of this study was to assess the occurrence of glycopeptide-resistant strains of Staphylococcus aureus in hospitalized patients undergoing treatment with vancomycin.

\section{MATERIALS AND METHODS}

\section{Hospital}

The Clinical Hospital of the Federal University of Uberlândia (UFU) is a 450 bed hospital that also provides and holds tertiary services.

\section{Study design}

A prospective, longitudinal study of 41 patients, which included 20 children enrolled in the Pediatric Clinic and 21 adult surgical patients undergoing treatment with vancomycin, was done from December 2000 to March 2002. Bacterial colonization of the patient was monitored by microbiological screening throughout the study. All patients (or parents, in the case of children) provided verbal consent before being enrolled. A standard clinical form, which included demographic data, the clinical diagnosis, and intrinsic and extrinsic risk factors, was completed for each patient.

\section{Microbiological techniques}

Specimens were collected by swabing (Bionete, São Paulo, Brasil) oral and rectal cavities within the first $24 \mathrm{~h}$ of treatment and then at weekly intervals until discharge or death of the patient. The material was transported to the microbiology laboratory at UFU in test tubes containing brain heart infusion BHI agar (Difco, Sparks, USA). Primary cultures were done in mannitol salt agar (Difco, Sparks, USA) containing $4 \mu \mathrm{g}$ of oxacillin/mL (Sigma Chemical Co., St. Louis, USA) incubated for $48 \mathrm{~h}$ at $35^{\circ} \mathrm{C}(11,12)$.

The isolates were identified to the level of genus/species using classic tests that included Gram staining, mannitol fermentation, and coagulase and catalase activities $(16,17)$.

Screening for hetero-VRSA was performed by spreading $100 \mu \mathrm{L}$ of the cell suspension adjusted to approximately $10^{8}$ colony-forming units $/ \mathrm{mL}$, onto the agar plates containing vancomycin, followed by incubation for $48 \mathrm{~h}$ at $35^{\circ} \mathrm{C}$. Bacterial growth was inspected 24 and 48 hours after the beginnig of incubation $(12,17)$.

\section{Molecular techniques}

Genomic DNA was extracted according Santos et al. (21) and quantified at $260 \mathrm{~nm}$ in a Hitachi U-2000 spectrophotometer. The quality of the DNA was assessed in $1 \%$ agarose gel (20).

RAPD-PCR assays were done as described by Welsh and McClelland (24). Thirty-one primers were screened and seven informative primers were selected (OPT 6, 14, 114, 127, 167, 180 and 243). The reactions were amplified in MJ Research PTC100 thermal cycler with two initial cycles of $94^{\circ} \mathrm{C}$ for $1 \mathrm{~min}, 37^{\circ} \mathrm{C}$ for $1 \mathrm{~min}$ and $72^{\circ} \mathrm{C}$ for $2 \mathrm{~min}$, followed by 33 cycles of $94^{\circ} \mathrm{C}$ for $10 \mathrm{~s}, 40^{\circ} \mathrm{C}$ for $20 \mathrm{~s}$ and $72^{\circ} \mathrm{C}$ for $2 \mathrm{~min}$ and $4^{\circ} \mathrm{C}$ for as long as necessary. The PCR products were separated in $1.5 \%$ agarose gels containing ethidium bromide $(0.5 \mu \mathrm{g} / \mathrm{mL})$. The bands were visualized and photographed in a VDS imaging system (Amersham Biosciences).

\section{Statistical analysis}

The electrophoretic profiles of the eight samples were compared with each other using a binary matrix based on the absence ( 0 ) and presence (1) of bands. The matrix generated by the Statistica $4.5^{\mathrm{A}}(1993)$ program was used to calculate of genetic distances and to run the cluster analysis. The genetic distances were calculated using the percentage disagreement method given by the formula $\mathrm{N}_{\mathrm{AB}}{ }_{\mathrm{AB}} / \mathrm{N}_{\mathrm{T}}$, where $\mathrm{N}_{\mathrm{AB}}$ is the number of polymorphic banding patterns and $\mathrm{N}_{\mathrm{T}}$ is the total number of banding patterns (1). Cluster analysis was done with the unweighted pair-group method using arithmetic averages (UPGMA), in which samples are grouped based on their similarity. Epi Info (6.03) program were used for the epidemiological analysis (2).

\section{RESULTS}

Methicillin/oxacillin-resistant Staphylococcus were isolated from $32(78.0 \%)$ out of 41 patients, including $21(51.2 \%)$ and 18 (43.9\%) individuals colonized by MRSA and MRCoNS, respectively. Eight patients (19.5\%) had hVISA. One patient initially colonized with hVISA showed the phenotype VISA (MIC for vancomycin $=8 \mu \mathrm{g} / \mathrm{mL}$ ) at a second sampling.

Six adults (average age of 43.5 years) and two children showed vancomycin-heteroresistant Staphylococcus aureus. The average duration of the treatment with vancomycin at the time of isolation was 15.3 days and the average time that these patients had been interned was 40.3 days.

Intrinsic rather than extrinsic factors such as three or more antimicrobial agents, surgery, and use of three or more invasive procedures, were related $(P<0.05)$ with hVISA colonization (Table 1).

Table 2 shows the susceptibility of the MRSA (17) and MRCoNS (20) isolates to vancomycin based on the MIC and heteroresistance. One Staphylococcus aureus with MIC of 8 $\mu \mathrm{g} / \mathrm{mL}$ behaved like VISA. The $\mathrm{MIC}_{90}$ for isolates of this microorganism was $4 \mu \mathrm{g} / \mathrm{mL}$. Eight isolates showed heteroresistance and grew at a vancomycin concentration $>5$ $\mu \mathrm{g} / \mathrm{mL}$.

Figs. 1 and 2 show the RAPD-PCR and the dendogram results for the eight hVISA isolates. RAPD-PCR identified two clusters with a dissimilarity of $63 \%$. The first group included the genotypes A, B, D, E, G and D H, while the second group included the genotypes $\mathrm{C}$ and $\mathrm{F}$, which had similar banding patterns (99.8\% similarity). Both groups (D, H and C, F) showed 
Table 1. Colonization by MRSA and MRCoNS heteroresistant to vancomycin in patients on vancomycin therapy at the Clinical Hospital, Uberlândia.

\begin{tabular}{|c|c|c|c|c|c|}
\hline \multirow{3}{*}{ Variables } & \multicolumn{5}{|c|}{ Colonized patients } \\
\hline & \multicolumn{3}{|c|}{ Yes $(\mathrm{N}=32)$} & \multirow{2}{*}{$\begin{array}{c}\text { No }(\mathrm{N}=9) \\
(9)\end{array}$} & \multirow[t]{2}{*}{$P$} \\
\hline & $\begin{array}{l}\text { hVISA } \\
\text { (8) }\end{array}$ & $\begin{array}{c}\text { hVICoNS } \\
\text { (4) }\end{array}$ & $\begin{array}{c}\text { VSSA/VSCoNS } \\
\text { (20) }\end{array}$ & & \\
\hline Adults & 6 & 2 & 9 & 4 & 0.20 \\
\hline Children & 2 & 2 & 11 & 5 & 0.20 \\
\hline $\operatorname{Sex}(M / F)$ & $4 / 4$ & $2 / 2$ & $9 / 11$ & $4 / 5$ & - \\
\hline Age (variation) & $33.4(2-79)$ & $20.3(0.3-63)$ & $25.6(0.5-79)$ & $15.7(0.4-40)$ & - \\
\hline \multicolumn{6}{|l|}{ Internment unit } \\
\hline \multicolumn{6}{|l|}{ Pediatrics } \\
\hline Onco-hematological & 1 & 1 & 3 & 3 & 0.77 \\
\hline General & 1 & 1 & 6 & 2 & 0.46 \\
\hline \multicolumn{6}{|l|}{ Surgical } \\
\hline Neurological & 2 & 1 & 5 & 2 & 0.95 \\
\hline Traumatological & 3 & 1 & 3 & 2 & 0.26 \\
\hline Urological & 1 & 0 & 3 & 0 & 0.84 \\
\hline \multicolumn{6}{|l|}{ Intrinsic risk factors } \\
\hline Duration of internment & $36.0(15-59)$ & $40.7(18-60)$ & $36.9(19-60)$ & $23.5(11-38)$ & - \\
\hline Re-internment & 3 & 1 & 8 & 1 & 0.88 \\
\hline Immuno-compromising & 4 & 1 & 4 & 2 & 0.17 \\
\hline \multicolumn{6}{|l|}{ Extrinsic risk factors } \\
\hline$\geq 3$ antimicrobials & 4 & 3 & 6 & 1 & 0.03 \\
\hline 3rd generation cephalosporin & 3 & 4 & 2 & 7 & 0.10 \\
\hline Surgery & 7 & 3 & 10 & 4 & 0.04 \\
\hline \multicolumn{6}{|l|}{ Invasive procedures } \\
\hline Central vascular catheter & 4 & 1 & 7 & 4 & 0.82 \\
\hline Peripheral vascular catheter & 8 & 4 & 19 & 5 & 0.12 \\
\hline Breathing & 5 & 0 & 5 & 0 & 0.10 \\
\hline Drain & 4 & 2 & 3 & 5 & 0.17 \\
\hline$\geq 3$ procedures & 7 & 4 & 13 & 4 & 0.01 \\
\hline
\end{tabular}

hVISA - heteroresistant vancomycin intermediate Staphylococcus aureus; hVICoNS - heteroresistant vancomycin intermediate coagulasenegative staphylococci; VSSA - vancomycin susceptible Staphylococcus aureus; VSCoNS - vancomycin susceptible coagulase-negative staphylococci.

differences according to classic epidemiology. This result was later confirmed by molecular study, suggesting horizontal transmission.

\section{DISCUSSION}

In this study, $19.5 \%$ of patients on prolonged treatment with vancomycin were colonized by Staphylococcus aureus resistant to this antimicrobial agent. These isolates belonged to the MRSA phenotype, as also reported in Japan $(10,12)$, the United States (3,13), Europe (15) and Brazil (6,16). Risk factors such as the length of internment (34.3 days), surgery (58.5\%), infection (100\%), use of the wide-range cephalosporins (53.7\%) and three or more invasive procedures $(68.3 \%)$ were associated with colonization by vancomycin-resistant Staphylococcus aureus. The frequency of colonization by MRSA and/or MRCoNS (78.0\%) reflected the seriousness of the situation and justifies more caution in hospitals. Infections by MRSA are endemic, accounting for almost half of infection by staphylococci in the Clinical Hospital at UFU (17). There observations along with the empirical use of antimicrobial agents in hospitals in developing countries $(5,7,8,25)$, increase the risk of emergence of glycopeptide-resistant Enterococcus and Staphylococcus. 
Table 2. $\mathrm{MIC}\left(=10^{6} \mathrm{CFU} / \mathrm{mL}\right)$ and Heteroresistance $\left(\geq 10^{8} \mathrm{CFU} /\right.$ $\mathrm{mL}$ ) of vancomycin in MRSA and MRCoNS samples isolated from patients in the Clinical Hospital, Uberlândia, from December 2000 to March 2002.

\begin{tabular}{ccccc}
\hline $\begin{array}{c}\text { Vancomycin } \\
(\mu \mathrm{g} / \mathrm{mL})\end{array}$ & MRSA** & & MRCoNS*** & \\
\hline MIC: & $\mathrm{N}$ & $\%$ & $\mathrm{~N}$ & $\%$ \\
\hline 0.25 & - & - & - & - \\
0.5 & 1 & 5.88 & 5 & 25 \\
1 & 5 & 29.41 & 6 & 30 \\
2 & 5 & 29.41 & 5 & 25 \\
4 & 5 & 29.41 & 4 & 20 \\
8 & 1 & 5.88 & - & - \\
Heteroresistance* & & & & \\
0.5 & 1 & 5.88 & - & - \\
1 & 3 & 17.64 & 2 & 10 \\
2 & 3 & 17.64 & 6 & 30 \\
3 & - & - & 1 & 5 \\
4 & 2 & 11.76 & 7 & 35 \\
5 & - & - & 1 & 5 \\
6 & 2 & 11.76 & 2 & 10 \\
7 & - & - & - & - \\
8 & 5 & 29.41 & 1 & 5 \\
9 & 1 & 5.88 & - & - \\
Total & 17 & 100 & 20 & 100 \\
\hline
\end{tabular}

* Inoculum $\geq 10^{8} \mathrm{CFU} / \mathrm{mL}$; ** MRSA - methicillin-resistant Staphylococcus aureus; $* * *$ MRCoNS - methicillin-resistant coagulasenegative staphylococci.

Exposure to vancomycin was the most evident risk factor in all patients from whom these microorganisms were isolated (13). The intrinsic risk factors include renal insufficiency and previous infection by MRSA $(13,21)$. In our series, the only patient on hemodialysis had VISA and in the total eight patients $(19.5 \%)$ were infected by hVISA; most patients (80\%) were colonized by methicillin/oxacillin-resistant Staphylococcus.

Staphylococcus isolates with reduced susceptibility to vancomycin are not detected by the disk diffusion technique (3) and tests in BHI agar containing 4 or $6 \mu \mathrm{g}$ of vancomycin use, determination of the MIC or E test are required $(3,13,23)$. The E test was not used in the present investigation. The hVISA and $\mathrm{hVICoNS}$ isolates were detected using a larger inoculum; $\cong 10^{8} \mathrm{UFC} / \mathrm{mL}$ in plates containing $1 \mu \mathrm{g}-10 \mu \mathrm{g}$ of vancomycin/ $\mathrm{mL}$, according to Hiramatsu et al. (10).

The evidence that two clusters were associated with hVISA is a cause for concern mainly because of the precariousness of the measures for controlling infection and because of the indiscriminate use of antimicrobial agents in Brazilian hospitals

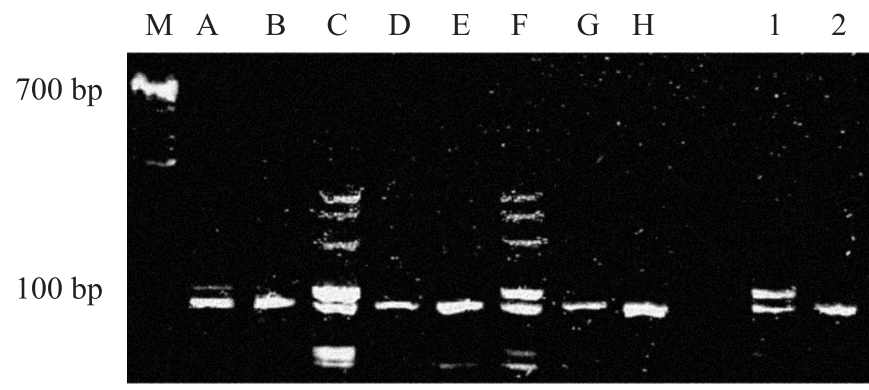

Figure 1. Electrophoresis (1.5\% agarose gel) of products amplified with primer 180. M DNA molecular weight markers, A to $\mathrm{H}$ - samples of vancomycin-heteroresistant, 1 Staphylococcus aureus ATCC 25923 and 2 - vancomycin resistant Staphylococcus haemolyticus 225r.

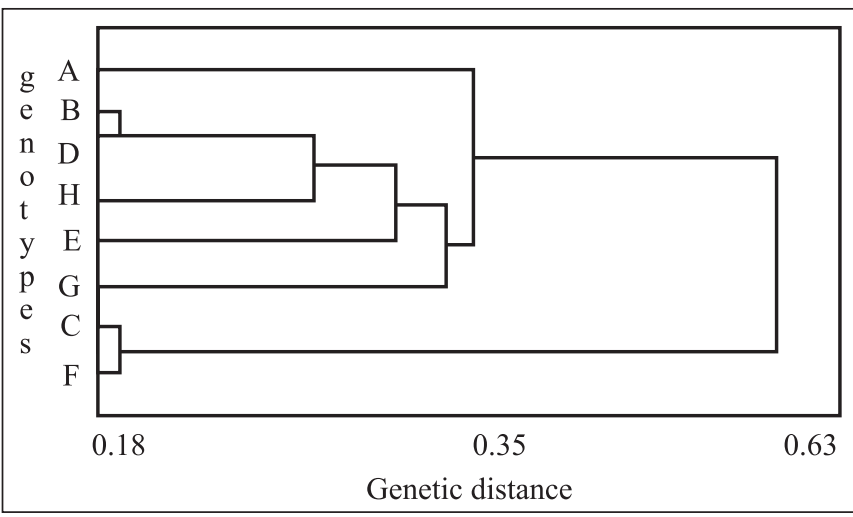

Figure 2. Dendogram featuring data of genetic distance by disagreement percentage and UPGMA method among the eight genotypes of Staphylococcus aureus based upon 58 RAPD markers obtained for short primers.

(14). This situation raises the risk of the emergence of multiresistance microorganisms emergency, including vancomycinresistant Staphylococcus and Enterococcus (9).

In contrast to reports of microorganisms with outstanding epidemiological resistance, have been few reports of the risk factors associated with the appearance of Staphylococcus aureus that have reduced susceptibility to vancomycin, $(10,22)$. Thus, the wise use of vancomycin and the adoption of adequate measures to control infection are necessary in order to avoid the emergence of glycopeptide-resistant microorganisms and their dissemination within hospitals.

The clinical cases of vancomycin-resistant Staphylococcus aureus (VRSA) reported here may be indicative of a higher and insidious prevalence of $\mathrm{hVRSA}$ and of $\mathrm{hVRCONS}$, in the Clinical Hospital at UFU. This relationship suggests transmission between adult patients interned in surgical units. 


\section{RESUMO}

\section{Análise da diversidade genética do Staphylococcus aureus resistente à vancomicina}

Staphylococcus aureus resistente à meticilina (MRSA) e Staphylococcus coagulase negativo resistente à meticilina (MRCoNS) são os agentes mais freqüentes em infecções hospitalares mundialmente, justificando o incremento no uso de vancomicina. Neste estudo avaliamos a presença de Staphylococcus resistentes aos glicopeptideos em 41 pacientes, em uso de vancomicina, hospitalizados no Hospital de Clínicas da Universidade Federal de Uberlândia em Uberlândia-MG. Todos os isolados foram semeados em agar Mueller-Hinton acrescido do antimicrobiano. A resistência a vancomicina foi confirmada por crescimento após incubação por 24-48 horas a $35^{\circ} \mathrm{C}$. A heterorresistência foi avaliada por semeadura com inóculo mais denso $\left(10^{8} \mathrm{UFC} / \mathrm{mL}\right)$. Um paciente com nefrite, no programa de hemodiálise teve o fenótipo de Staphylococcus aureus com resistência intermediária à vancomicina (VISA) $(\mathrm{CIM}=8 \mu \mathrm{g} / \mathrm{mL})$ e em oito pacientes as amostras apresentaram heterorresistência (hVISA). Além do uso prévio de vancomicina outros fatores de risco incluindo três ou mais antimicrobianos, cirurgia e três ou mais procedimentos invasivos, foram observados. A análise molecular foi realizada por amplificação randômica de DNA polimórfico em reação em cadeia da polimerase (RAPD-PCR) mostrando dois clusters com duas amostras cada um, em pacientes cirúrgicos, com relação temporal espacial e com perfil de susceptibilidade semelhantes quando frente à vários outros antimicrobianos.

Palavras-chave: epidemiologia hospitalar, Staphylococcus aureus resistente à vancomicina, RAPD-PCR

\section{REFERENCES}

1. Cabral, T.A.T. Divergência genética entre genótipos de algodoeiro (Gossypiu hirsutum) estimada por análise de marcadores RAPD. Uberlândia, 1997, 54 p. (Master Thesis. Instituto de Ciências Biomédicas, UFU).

2. CENTER FOR DISEASES CONTROL AND PREVENTION (CDC) \& World Health Organization (WHO). Epi info 6: a world processing, database and statistics program for public health. Vs 6.03. Atlanta and Geneve, Switzerland, 1996.

3. CENTER FOR DISEASES CONTROL AND PREVENTION. Staphylococcus aureus with reduced susceptibility to vancomycin. MMWR Morb. Mortal. Wkly Rep., 46, 765-766, 1997.

4. CENTER FOR DISEASES CONTROL AND PREVENTION . Staphylococccus aureus resistant to vancomycin. MMWR Morb. Mortal. Wkly Rep., 51, 565-567, 2002.

5. Couto, H.G.; Leles, C.C.V.; Lima, H.V.; Assunção, U.F.; Ribas; R.M.; Diogo Filho, A.; Gontijo Filho, P.P. Vancomycin use in a Brazilian university hospital. Comparison with hospital infection control practices advisory Committee guidelines. VI Congresso Brasileiro de Controle de Infecção e Epidemiologia Hospitalar, Rio de Janeiro, 1998. p. 188.
6. Del'Alamo, L.; Huband, M.D. Antimicrobial susceptibility of coagulase-negative staphylococci and characterization of isolates with reduced susceptibility to glycopeptides. Diagn. Microbiol. Infect. Dis., 34, 185-191, 1999.

7. Goldmann, D.A.; Huskins, W.C. Control of nosocomial antimicrobialresistant bacteria: a strategic priority for hospitals worldwide. Clin. Infect. Dis., 24, 39-45, 1997.

8. Gontijo Filho, P.P. Definições de infecções hospitalares sem a utilização de critérios microbiológicos e sua consequência na vigilância epidemiológica no Brasil. NewsLab., 53, 120-124, 2002.

9. Guzmám-Blanco, M.; Casellas, J.M.; Sader, H.S. Bacterial resistance to antimicrobial agents in Latin America. Infect. Dis. Clin. North Am., 14:67-81, 2000.

10. Hiramatsu, K.; Aritaka, N.; Hanaki, H.; Kawasaki, S.; Hosoda, Y.; Kobayashi, I. Dissemination in Japanese hospitals of strains of Staphylococcus aureus heterogeneously resistant to vancomycin. Lancet., 350, 1670-1673, 1997.

11. Hiramatsu, K. Vancomycin resistance in staphylococci. Drug Resist. Updat., 1, 135-150, 1998.

12. Hiramatsu, K. Vancomycin-resistant Staphylococcus aureus: a new model of antibiotic resistance. Lancet Infect. Dis., 1, 147-155, 2001.

13. Laley, R.T.; Lanz, E.; Schrock, C.G.; Rapid control of an outbreak of Staphylococcus aureus on a neonatal intensive care department using standard infection control practices and nasal mupirocin, Am. J. Infec. Control., 32, 44-47, 2004.

14. Lutz, L.; Machado, A.; Kuplic, N.; Barth, A.L. Clinical failure of vancomicin treatment of Staphylococcus aureus infection in a tertiary care hospital in southern Brazil. Braz. J. Infect. Dis., 7(3), 224-228, 2003

15. Marchese, A.; Balistreri, G.; Torroli, E.; Schito, G.C. Heterogeneous vancomycin resistance in methicillin-resistant Staphylococcus aureus strains isolated in a large Italian hospital. J. Clin. Microbiol., 38, 866-869, 2000

16. Nunes, A.P.F. Staphylococcus coagulase-negativos: diferenciação em espécies, diversidade genômica de espécies resistentes à oxacilina e determinação da susceptibilidade à glicopeptídios. Rio de Janeiro, 2000, 97 p. (Master Thesis, Universidade Federal do Rio de Janeiro).

17. Oliveira, G.A.; Dell'Aquila, A.M., Masiero, R.L.; Levy, C.E.; Gomes, M.S.; Cui, L.; Hiramatsu, K.; Mamizuka, E.M. Isolation in Brazil of nosocomial Staphylococcus aureus with reduced susceptibility to vancomycin. Infect. Control Hosp. Epidemiol., 22, 443-448, 2001.

18. Oteo, J.; Baquero, f.; Vindel, A.; Campos, J. Antibiotic rsistance in 3113 blood isolates of Staphylococcus aureus in 40 Spanish hospitals participating in the European Antimicrobial Resistance Surveillance System (2000-2002). J. Antimicrob. Chemoth., 53, 1033-1038, 2004.

19. Sadoyama, G.; Gontijo Filho, P.P. Risk factors for methicillin resistant and sensitive Staphylococcus aureus infection in a Brazilian university hospital. Braz. J. Infect. Dis., 4, 135-143, 2000.

20. Sambrook, J.; Fritsch, E.F.; Maniatis, T. Molecular cloning: a Laboratory Manual. CSH Laboratory Press, 1989.

21. Santos, L.R.; Nascimento, V.P.; Oliveira, S.D.; Flores, M.L.; Pontes, A.P.; Salle, C.T.P.; Lopes, R.F.F. Polymerase chain reaction (PCR) for the detection of Salmonella in artificially inoculated chicken meat. Rev. Inst. Med. Trop. Sao Paulo., 43, 247-250, 2001.

22. Srinivasan, A.; Dick, J.D.; Perl, T.M. Vancomycin resistance in staphylococci. Clin. Microbiol. Rev., 15, 430-438, 2002.

23. Tenover, F.C. VRSA, VISA, and GISA: the dilemma behind the name game. Clin. Microbiol. Newsl., 22, 49-52, 2000.

24. Welsh, J.; McClelland, M. Fingerprint genomes using PCR with arbitrary primers. Nucleic Acids Res., 18, 7213-7218, 1990.

25. Wey, S.B. Infection control in a country with annual inflation of 3,600\%. Infect. Control Hosp. Epidemiol., 16, 175-178, 1995. 